This is an Accepted Manuscript of an article published by Taylor \& Francis in Coaching: An International Journal of Theory, Research and Practice on February 2015, available online: http://dx.doi.org/10.1080/17521882.2015.1009134

\title{
Is Managerial Coaching a source of Competitive Advantage? Promoting Employee Self-Regulation through Coaching
}

Dr. Claudio Pousa ${ }^{1}$, Faculty of Business Administration, Lakehead University, Canada Dr. Anne Mathieu, Faculté d'Administration, Université de Sherbrooke, Canada

\begin{abstract}
The present business environment of extreme competition and rapid changes has motivated scholars to identify variables that can help companies stand up to and overcome these challenges. Research on self-regulation found that self-perceptions of efficacy not only can mediate the effects of external influences on results, but can also regulate employees' initiation, persistence and choice of purposeful actions. Within the selfregulatory framework, this paper specifically explores the role of managerial coaching as an antecedent of employee self-efficacy and performance. Using a sample of 122 Financial Advisors, we found that managerial coaching can increase employee self-efficacy, which in turn fully mediates the effects of coaching on results and behavioural performance. We suggest that, if generalized use of coaching by managers can increase employees' selfefficacy (which is instrumental in increasing employees' initiation and persistence of coping behavior when faced with challenges and problematic situations), then the use of managerial coaching by an organization might promote employee self-regulation, increase the organization's general resilience and, thus, can be considered a sustainable competitive advantage.
\end{abstract}

Keywords: Coaching, Self-regulation, Self-efficacy, Performance, Social Cognitive Theory, Competitive advantage, Salespeople, Canada

\footnotetext{
${ }^{1}$ Corresponding author. Email: cepousa@1akeheadu.ca
} 


\section{Practice points}

- This study is particularly relevant to the practice of managerial coaching and its application in organizations. The main contribution is that managerial coaching can increase employee's self-efficacy, behavioural performance and results performance.

- Previous research in self-regulatory behaviour found that people with high self-efficacy set higher and more difficult goals, are more committed to them, initiate actions to cope with problematic situations, spend more effort, persist longer in goal pursuit and make better choices of activities and settings.

- Accordingly, the systematic use of managerial coaching by an organization can increase the self-regulatory behavior of all its employees through its direct effect on self-efficacy, thus increasing their collective effort, their resilience when faced with challenging circumstances and their flexibility to deal with those circumstances and implement new solutions. As such, managerial coaching can be considered a dynamic competitive advantage of the organization.

\section{Introduction}

In the present business environment organizations are subjected to increased competition, fastpaced change and pressures from different stakeholders. Other environmental conditions, particular to commercial organizations, are rapid changes in products and technologies, shortened product development cycles, increased demands from customers and other stakeholders, channel restructuration and changes in buying processes (Ingram, LaForge, Locander, MacKenzie \& Podsakoff, 2005). Under these conditions, managers and employees alike are required to be more responsive, and deploy more effort and imagination in order to help 
their organizations achieve higher performance.

This situation is particularly critical in the case of salespeople who face numerous challenges. Sales representatives perform a difficult job, are usually away from the facility where the rest of the employees work, have more latitude regarding the use of their time and effort, have variable remuneration schemes, and work at the boundaries of the organization (Ingram et al., 2005).

One key construct that can help salespeople cope with these challenges is self-efficacy. Perceptions of own efficacy have been linked to "both the initiation and persistence of coping behavior" (Bandura, 1977, p. 193). "Perceived self-efficacy concerns people's beliefs in their capabilities to mobilize the motivation, cognitive resources and courses of action needed to exercise control over events" (Wood and Bandura, 1989, p. 364). Thus, people with high selfefficacy are more prone to initiate actions to cope with a given situation, spend more effort when faced with unexpected problems, persist longer in face of rejection and make better choices (Bandura, 1977, 1982; Latham and Locke, 2007; Latham and Seijts, 1999; Latham and Pinder, 2005; Locke and Latham, 1990, 2002, 2006; Stajkovic and Luthans, 1998).

Given the centrality of self-efficacy for human agency, scholars explored ways of increasing it. In the field of coaching, scholars found initial support for the relationship between coaching and self-efficacy in fields as diverse as personal systems coaching (Gordon Bar \& St.Rosh-Ha'Ayin, 2014) and executive coaching (Baron \& Morin, 2010; Moen \& Allwood, 2009).

Despite sharing a common basis and origins (Hagen, 2012), executive coaching and managerial coaching differ in several respects (Pousa, 2012; Pousa \& Mathieu, 2014b). In executive coaching processes, an external coach works with a top executive in order to help him/her achieve self-defined goals (or sometimes, mutually identified goals), improve his/her 
professional performance and personal satisfaction, and consequently improve the effectiveness of the organization (Joo, 2005; Kilburg, 1996). In managerial coaching a manager uses coaching as a managerial tool to help his/her subordinates achieve a series of externally-set organizational goals and increase their job-related performance. For example, in the case of salespeople, the organization establishes a performance goal for each sales representative (usually expressed as a monthly sales quota), the manager communicates this goal to the salesperson, and the salesperson is expected to engage in activities that will allow him/her achieve the goal.

Given the differences between executive and managerial coaching established in the literature, including this fundamental difference between the ways that goals are established, it would be useful to know whether managerial coaching is also a valid tool to increase employee selfefficacy. A rationale for this question can be the following: when coachees choose their own goals or participate in goal definition, as is the case of executive coaching, then Goal-setting theory suggests that their goal commitment will be high (Latham and Locke, 2007; Latham and Seijts, 1999; Latham and Pinder, 2005; Locke and Latham, 1990, 2002, 2006; Seijts and Latham, 2001) and, thus, they are more likely to develop high commitment to the process (executive coaching) that would allow them achieve the goals. On the other hand, when goals are externally imposed, goal commitment would be lower (Locke and Latham, 1990, 2002, 2006) and thus the coachee commitment with the process (managerial coaching) would also be lower, thus leading to mitigated effects of the coaching intervention.

These reasons support the pertinence of exploring managerial coaching as an antecedent of selfefficacy and performance. 


\section{Theoretical framework}

\section{Self-efficacy}

Self-efficacy is a construct derived from Social Cognitive Theory, a theory that proposes a reciprocal causation model, in which individual behavior, cognition and the environment dynamically interact and influence each other (Gist and Mitchell, 1992). The concept of selfefficacy blossomed during the 1970s in the psychological literature, and it was useful to explain how people acquired and regulated their behaviors in order to cope with circumstances and achieve outcomes (Bandura, 1977). Perceived self-efficacy is concerned with "judgments of how well one can execute courses of action required to deal with prospective situations" (Bandura, 1982, p. 122).

Research found that people base their expectations of personal efficacy on four major sources of information: past performance accomplishments, vicarious experience, verbal persuasion and physiological states (Bandura, 1977; Gist and Mitchell, 1992; Wood and Bandura, 1989). However, self-efficacy is "a comprehensive summary or judgment of perceived capability of performing a task" (Gist and Mitchell 1992, p. 184), meaning that it is the individual's cognitive appraisal and integration of these sources which ultimately defines his/her level of self-efficacy.

In the context of performance appraisal, coaching has been identified as a valid mechanism "to instill the desire within employees to continuously improve performance" (Latham and Wexley 1994, p. 206) by acting upon two key variables: an employee's outcome expectancies and their self-efficacy. Therefore, the authors proposed that "the job of coaching is to strengthen an employee's self-efficacy regarding a specific task so that there is an inextinguishable sense of commitment that is resilient to drawbacks and rejections" (Latham and Wexley 1994, p. 208). 
The coaching intervention influences coachee's judgments of self-efficacy. During the coaching intervention, the manager and the employee work together to tackle a problematic situation and to arrive at specific solutions that the employee will implement in the weeks following the intervention; initially, the coach reviews the employee's past performance, and gives him/her focused feedback; following this, they target the problems that the employee might be facing, they cover the different alternatives and actions to be taken, the resources needed, the support required by the employee, and his confidence in implementing the actions; finally, they agree upon a set of actions which will be implemented in the weeks to come (Richardson, 2009). Having decided on what actions to take and when, and having role-played them with the coach, the coachee exits the coaching conversation with a reinforced perspective that he/she is capable of facing the challenges to come. Accordingly:

$H_{1}$ : Managerial coaching positively influences employee's self-efficacy.

\section{Performance}

The determinants of employee performance is an extensively researched subject (particularly in the case of sales force performance) and numerous studies agree that it can be analyzed from a behavioral or a results perspective, corresponding to behavioral or results performance (Fang, Palmatier and Evans, 2004). Additionally, recent studies on coaching found initial support for the impact of coaching on employee performance, in contexts like logistics (Ellinger, Ellinger and Keller, 2003) or sales (Agarwal, Angst and Magni, 2009; Pousa, 2012; Pousa and Mathieu, 2014a, 2014b; Trépanier, 2010). In line with these previous results we propose that:

$\mathrm{H}_{2}$ : Managerial coaching positively influences employee's behavioural performance. 
$H_{3}$ : Managerial coaching positively influences employee's results performance.

Although the literature makes a distinction between behavior and results performance and treats them separately, these two constructs are not independent but related. While results performance is directly related with the end results achieved by the employees (e.g. contributing to increase the company's margins and market share, identifying potential accounts or achieve sales targets and quotas), behavior performance is more related to the process that employees follow in order to achieve those results (e.g. developing good relations with customers, assisting their supervisors and helping them achieve their goals or managing time and expenses). Accordingly, a high level of behavior performance can be desired, first as an end in itself, but also because of the impact that it can have on results performance (Fang et al., 2004). Accordingly, we propose that:

$H_{4}$ : Employee's behavioural performance positively affects results performance

Finally, the resulting evidence from different meta-analysis shows that beliefs of one's own efficacy significantly contribute to individual motivation and performance (Bandura and Locke, 2003). The results of one of these recent meta-analyses showed a significant weighted average correlation between self-efficacy and work-related performance of 0.38 , after being adjusted for sample size, outliers and extreme values (Stajkovic and Luthans, 1998). The rationale for these results lies in the fact that "expectations of personal mastery affect both the initiation and persistence of coping behavior" (Bandura, 1977, p. 193), thus people with high self-efficacy will initiate actions to cope with a given situation, will spend more effort, will persist longer and will make better choices of activities and settings, compared to people with low self-efficacy (Bandura, 1977, 1982; Stajkovic and Luthans, 1998). Accordingly: 
$H_{5}$ : Employee's self-efficacy positively affects his/her behavioural performance.

$H_{6}$ : Employee's self-efficacy positively affects his/her results performance.

\section{Method}

\section{Research design and data collection procedure}

We decided to use a non-experimental design for our study because coaching is a behavior that a manager has to develop through years of training and practice (Grant, 2010; Grant \& Hartley, 2013) not a variable that could be easily manipulated in a laboratory setting. This decision is supported by previous research in managerial coaching, as scholars extensively used nonexperimental designs to study it and to test its effects on other constructs (Agarwal et al., 2009; Ellinger et al., 2003, 2005, 2008; Onyemah, 2009; Pousa, 2012; Pousa and Mathieu 2014a, 2014b; Trépanier, 2010).

A large Canadian bank agreed to participate in the study by allowing their Financial Advisors (front-line employees holding customer service and sales responsibilities for a portfolio of financial products) to answer a survey during office time. Given the equivalence of paper-andpencil and web-based surveys (Smither, Walker \& Yap, 2004) and the convenience, speed, flexibility and low-cost offered by the latter, we decided to use a web-based survey and host our questionnaire with a European company offering these services. The bank provided us with the e-mails of 373 Financial Advisors and we sent them an initial invitation to participate, followed by a reminder two weeks later. A hyperlink to the electronic survey was provided in both the invitation and the follow-up mails, and by clicking in it the individuals agreed to participate voluntarily in the study. 


\section{Measures}

We used existing measuring scales from the literature in coaching, sales and marketing. Managerial coaching was measured using eight items from Ellinger et al. (2003). This is a unidimensional measure that presented good psychometric properties and stability in many different studies. Self-efficacy was measured using 4 items from Sujan, Weits \& Kumar (1994). This is also a unidimensional scale, with good psychometric properties, which has been extensively used in marketing and sales research. Finally, behavioral and results performance were measured using the scales presented in Fang et al. (2004). The behavioural performance scale used three items, while the results performance used seven. Both scales are unidimensional. All scales were anchored at $1=$ strongly disagree and $7=$ strongly agree.

\section{Analysis}

\section{Sample}

Invitations to participate in the survey were sent to 373 Financial Advisors and 122 complete, usable questionnaires were received for a response rate of $32.7 \%$. The distribution of responses according to gender was slightly skewed towards females, with $69 \%$ of the sample comprising female and $31 \%$ male respondents.

Respondents had been receiving coaching for at least the last six months, although no data was collected concerning frequency of these interventions.

Table 1 presents the statistics concerning tenure with the company, in the position, and selling experience. Values suggest a great diversity and heterogeneity of employees, covering a broad 
range of experienced and inexperienced individuals, including people who have just accessed the position with others having held the position almost for their entire career, as well as individuals who are new to the company with others having worked for it almost for a lifetime. This heterogeneity suggests that the sample provides a good representation of a larger, general population.

\section{Place Table 1 near here}

\section{Reliability and validity of measuring scales}

Confirmatory factor analysis (run in AMOS 19) was used to evaluate the properties of the measurement model, which was estimated by restricting each scale's item loading on its a priori specified factor, and allowing free correlation among factors (Byrne, 2010; Gerbing and Anderson, 1988). Items showing standard regression weights lower than .50 or high crossloadings were eliminated; final factor loadings and reliabilities are presented in Table 2.

\section{Place Table 2 near here}

We assessed scales' reliability using three different indicators: Cronbach's alpha, corrected itemtotal correlations and composite reliability (Table 2). The scale with the lowest Cronbach's alpha was Self-Efficacy $(\alpha=.838)$ and the one with the highest was Coaching $(\alpha=.948)$; all four scales showed Cronbach's alpha values above the accepted threshold of 0.7 that suggests acceptable reliability (Nunnally, 1978). Concerning corrected item-total correlation, scales presented values ranging from .560 to .910 , all of them also above the accepted threshold that suggests acceptable reliability. Finally, composite reliability indexes (CR) ranged from .816 for Self-efficacy, to .881 for Behavioural performance, .913 for results performance and .950 for Managerial coaching. All these values exceeded the threshold of .6 necessary for measurement reliability (Bagozzi and Yi, 
1988; Fornell and Larcker, 1981). Globally, these results suggest that the scales present good reliability.

The average variance extracted (AVE) for the four factors rendered values of .703 for Coaching, .528 for Self-efficacy, .719 for Behavioural Performance and .601 for Results Performance (Table 2), also suggesting adequate convergent validity (Fornell and Larcker, 1981).

Discriminant validity of the measures was assessed by comparing the square root of the AVE values to the factor correlations; the results indicate that the square root of AVE for each factor is bigger than any of its correlations with the other factors (Table 3), suggesting adequate discriminant validity (Fornell and Larcker, 1981).

\section{Place Table 3 near here}

The fit indexes for the measuring model indicated a good fit between the model and the data (Byrne, 2010; Kline, 2011) with $\chi^{2}=341.23$, p<.01; Comparative Fit Index (CFI) = .94; root mean square error of approximation $($ RMSEA $)=.08$, Incremental Index of Fit $($ IFI $)=.94$; and Tucker Lewis Index $(\mathrm{TLI})=.93$.

\section{Results}

After the measuring model was deemed to be acceptable, we run the structural model to test the hypothesized relationships. The fit indexes $\left(\chi^{2}=359.02, \mathrm{p}<.01 ; \mathrm{CMIN} / \mathrm{DF}=1.80 ; \mathrm{CFI}=.93 ; \mathrm{IFI}\right.$ $=.93 ; \mathrm{TLI}=.92 ; \mathrm{RMSEA}=.08)$ suggest that the hypothesized model acceptably fit the data.

As hypothesized, supervisory coaching affects employee's self-efficacy $(\beta=.45, \mathrm{p}<.01)$ in 
support of $\mathrm{H}_{1}$; self-efficacy affects behavioral performance $(\beta=.51, \mathrm{p}<.01)$ in support of $\mathrm{H}_{5}$ and results performance $(\beta=.68, \mathrm{p}<.01)$ in support of $\mathrm{H}_{6}$; and behavioral performance affects results performance $(\beta=.40, \mathrm{p}<.01)$ in support of $\mathrm{H}_{4}$. Support was neither found for the direct link between coaching and behavioral performance $\left(\mathrm{H}_{2}\right)$ nor for coaching and results performance $\left(\mathrm{H}_{3}\right)$ (Table 4 and Figure 1); as we discuss in the next section, it seems that the mediating effect of self-efficacy captures all the variance in performance, thus turning the direct link between coaching and performance to non-significant.

\section{Place Table 4 and Figure 1 near here}

\section{Assessment of the Effects of Same-Source Bias}

Our data relied on information provided by the same respondent for both predictor and criterion variables; in this situation, a self-report bias might result from any artifactual covariance between these variables due to the fact that the person providing both answers is the same (Podsakoff, MacKenzie, Lee \& Podsakoff, 2003). Research has typically accepted that common method variance (CMV) might inflate or deflate correlations between constructs (Cote and Buckley, 1987; Podsakoff et al., 2003), although some scholars have proposed that CMV does not automatically affect or distort these correlations (Schmitt, 1994; Spector, 1987, 1994, 2006).

In order to assess the potential impact of this form of bias in our study, we reestimated the hypothesized model by adding a first-order factor (that could potentially account for CMV) to the indicators of coaching, self-efficacy, results performance and behavioral performance, as described in Podsakoff et al. (2003). The results of this analysis are shown in the last column of Table 4; the significance of the standardized regression weights for the model don't change when controlling for common method variance, and their sign and magnitude are similar when not 
controlling for CMV, thus suggesting that, even a small amount of CMV might still exist, it doesn't affect the conclusions of the study.

\section{Discussion}

The present business environment of increased competition and fast-paced change is demanding from organizations to be more responsive to these challenges and from its employees to initiate and persist in their coping behaviours when faced with them. One potential tactic that organisations can use to increase employees' initiation and persistence of coping behaviour is to use specific managerial tools that can promote this type of self-regulatory behaviour. Building on Social Cognitive Theory (Bandura, 1977) we proposed that managerial coaching is one of these tools, which can increase employee self-efficacy (one key construct in employee self-regulation) as well as employee behavioural and results performance.

Results support our hypotheses. They suggest that managerial coaching is a positive influence that can increase employee's self-efficacy, as well as results and behavioral performance through the full mediating effect of self-efficacy. The model proposed in this paper, although parsimonious, presents high values of explained variance in its central constructs. Twenty percent of the variance in self-efficacy can be explained by coaching, twenty-six percent of the variance in behavioural performance can be explained by self-efficacy, and eighty-five percent of the variance in results performance can be explained by the combined effect of self-efficacy and behavioural performance. These strong results lead us to elaborate on two main contributions of this article.

A first scientific contribution of this paper is the support found for the positive link between 
managerial coaching and employee self-efficacy. Previous research in executive coaching found some initial support for its positive impact on the coachee's self-efficacy (Baron \& Morin, 2010; Moen \& Allwood, 2009) but we are not aware of studies verifying this relationship for managerial coaching. This study found a positive and significant standardized path between managerial coaching and self-efficacy $(\beta=.45, \mathrm{p}<.01)$ as well as a high value of explained variance of the criterion variable $\left(\mathrm{r}^{2}\right.$ self-efficacy $\left.=.20\right)$.

We hypothesized this link based on Social Cognitive Theory and its associated research (Bandura, 1977, 1982; Gist \& Mitchell, 1992) but we also believe that there is a strong rationale that explains coaching's influence on self-efficacy that can be relevant for research and practice.

Bandura (1977) proposed that people base their expectations of personal efficacy on four major sources of information (past performance accomplishments, vicarious experience, verbal persuasion and physiological states) and later research found that people pass through three different processes through which the four sources of information are transformed into perceptions of efficacy: 1) the analysis of task requirements; 2) the attributional analysis of past experience; and 3) the assessment of personal and situational resources and constraints (Gist \& Mitchell, 1992).

These three processes are explicitly addressed during the coaching intervention. According to Richardson (2009), during the coaching intervention the manager (coach) provides focused feedback on the employee's past performance and achievements (process \#2, attributional analysis of past performance); moving forward in the coaching session, the coach and the employee (coachee) evaluate the tasks requirements (process \#1, analysis of task requirements) as well as the problems and challenges that the employee is facing that prevent her/him from 
achieving higher performance. Building on the employee's past performance and achievements (process \#2, attributional analysis of past performance) they explore different ways to overcome the new challenges (process \#3, assessment of personal and situational resources and constraints). Additionally, the coach provides constructive feedback and uses analogies and scenarios to help the employee learn through vicarious experiences. The coach asks questions, rather than providing solutions, in order to help the employee think through the issues and come up with alternative courses of action that can be role-played to help the employee see different perspectives (process \#3, assessment of personal and situational resources and constraints) (Richardson, 2009). After the coaching intervention, the employee has an increased perception that he or she is capable of executing better courses of action to overcome problems and challenges; this judgment of increased capability to carry on the tasks represents the employee increased self-efficacy.

A second scientific contribution of the paper is the effect found on behavioural and results performance. The model explains $26 \%$ of the variance in behavioural performance $\left(\mathrm{r}^{2}\right.$ behaviouralperformance $=.26)$ as well as $85 \%$ of results performance $\left(\mathrm{r}^{2}\right.$ results-performance $\left.=.85\right)$ by the combined effect of managerial coaching and self-efficacy. These are very significant values that further support the centrality of the independent (managerial coaching) and mediating (self-efficacy) variables chosen to explain performance.

However, results also suggest that, in the presence of self-efficacy, the direct link between coaching and performance becomes non-significant. This was somewhat unexpected, because the direct link between managerial coaching and employee performance has received widespread support in the scientific literature (Agarwal et al., 2009; Ellinger et al., 2003; Pousa and Mathieu, 2014b), and we were expecting a partial mediation effect of self-efficacy rather than a complete 
one. One potential explanation is that the overall magnitude of the relationship between selfefficacy and performance is so important, that it could be masking other effects. Results from a recent meta-analysis about self-efficacy and work related performance (Stajkovic and Luthans, 1998) suggest that the effect of self-efficacy represents a $28 \%$ gain in work related performance, which is much more important than the gain of $13.6 \%$ due to feedback interventions or $10.4 \%$ due to goal-setting found by other meta-analyses. Studies measuring the direct impact of managerial coaching on employee performance found correlations ranging from .03 and .06 (Pousa and Mathieu, 2014b), to .10 (Pousa and Mathieu, 2014a), .11 (Trépanier, 2010) and .13 (Agarwal et al., 2009). The weighted average correlation of .38 between self-efficacy and performance found by Stajkovic and Luthans (1998) outweighs these values and can potentially explain the full mediation effect found in this study.

\section{Managerial implications}

One initial implication of our research concerns the use of coaching as a managerial tool to increase employee self-efficacy and performance. Our sample specifically used employees who are in direct contact with customers and who have sales responsibilities, and we found that both the self-efficacy and the performance of such employees increased through the use of managerial coaching. Although the use of a purposive sample and a particular set of employees (salespeople) goes against the external generalizability of the results, we see no reason why the results cannot be applied to other employees in the organization (beyond those holding sales responsibilities).

Although one of the necessary conditions to external generalizability is the use of probabilistic samples, this criteria has not been respected in most organizational research; Schwab recognizes this when he expresses that "almost all of the empirical studies published in our journals ... use 
convenience samples ... thus if one took generalization to a population using statistical inference seriously, one would recommend rejecting nearly all manuscripts submitted" (Schwab, 1985, p. 173, cited by Robson, 2002, p. 267). In qualitative research, where researchers strongly rely on non-probabilistic samples, scholars have proposed to talk of transferability rather than generalizability (Guba and Lincoln, 1989). Other scholars have stressed the importance of aspects like the presumed universality of the phenomenon studied as factors enabling the generalizability of results to other contexts when nonrandom samples are used (Maxwell, 1997). In the case of this study, there are no reasons to think that the employees holding sales responsibilities should react differently to coaching than other employees in the organization. Thus, the use of a convenience, non-probabilistic sample does not automatically preclude the possibility of generalizing the expected results to a larger population of employees reporting to managers using coaching approaches.

If we accept the conclusions stated above, and managerial coaching can increase the self-efficacy of all the employees in a given organization, then the systematic use of coaching by an organization might increase the self-regulatory behavior of all its employees, thus increasing their collective effort, their resilience when faced with challenging circumstances and their flexibility to deal with those circumstances and implement new solutions. Previous research showed that people with high self-efficacy will choose higher and more difficult goals, will be more committed to them, will initiate actions to cope with problematic situations, will spend more effort, will persist longer in goal pursuit and will make better choices of activities and settings. Accordingly, the generalized use of coaching by all managers in an organization might be considered as a tool that can increase the competitive advantage of that organization through its positive effects on employee self-regulation. 
Research suggests that three key dimensions of employee self-efficacy can have important implications for performance. First, efficacy expectations vary in magnitude (an individual can have high self-efficacy for performing easy tasks, but less for performing difficult ones). Second, efficacy expectations also vary in generality (an individual can have high self-efficacy to perform general, non-specific tasks or to perform very specific and concrete tasks). And third, efficacy expectations vary in strength (when faced with disconfirming experiences, problems or low performance, an individual can be more or less resilient depending on the strength of the efficacy expectations) (Bandura, 1977).

These three dimensions also give some clues as to what the manager should do during the coaching intervention. Prior to the coaching intervention, the coach might engage in an observation of the employee to pinpoint the key areas where the intervention might focus. Additionally, he can prepare questions to use during the intervention that would raise the coachee's awareness about this situation. This should provide the coach with enough clues to identify the key issue to address during the coaching intervention. Experienced coaches suggest that during the coaching session the coach should focus on only one issue that will dramatically affect employee performance when solved. This single issue might deal with increasing the coachee's self-efficacy to perform a particularly difficult task (magnitude), or a specific task (generality) or his resilience to face problems or rejection (strength).

Once the key issue is identified, the coach can focus the intervention on helping the coachee address it and develop strategies to deal with it. After the coaching intervention, the coachee will have a better understanding of what is expected from him, how he would solve the issue, what are the available resources that he has access to, and what are the specific actions that he would undertake when faced with the situation in the future. His self-efficacy will be increased, thus 
providing a stronger basis for purposeful action, and more likely, better performance.

\section{Limits and future research}

The most important limitation probably is the choice of a purposive sample of a single organization. Although the concept of coaching has been around at least since the 1970s (Fournies, 1978) and practitioners have largely praised the positive effects of coaching (Corcoran et al., 1995; Hargrove, 1995; Kinlaw, 1989; Richardson, 2009; Whitmore, 1985) research on coaching is limited, it has been criticized for being predominantly practice-driven and guru-led, lacking solid theoretical basis, as well as for being mostly based on single-case studies (Ellinger et al., 2008; Grant and Cavanagh, 2004; Hamlin et al., 2006). Quantitatively, theory-based research in coaching is only at its beginnings and with few exceptions scholars have used singleorganization samples. Despite having used a solid and widely accepted theoretical framework for our study, the fact of having collected data within a single organization is indeed a limitation. Future research could build on these results by inviting other organizations worldwide to participate in a much larger survey, thus potentially increasing the external validity of the results.

Another limitation is that we used a single respondent to provide information about dependent and independent variables. Systematic measurement errors are issues of important consideration that have drawn a lot of attention in the scientific marketing literature, and using a common source is one of them (Cote and Buckley, 1987; Podsakoff et al., 2003; Schmitt, 1994; Spector, 1987, 1994, 2006). Although we evaluated the effects of bias due to a common respondent, and concluded that these effects were small and didn't affect the conclusions of the study, we cannot deny that they still might exist. Future research could address this limitation by using information from multiple sources, like employees, customers and managers. 
Finally, we believe that the results found in this study also open new (and interesting) avenues for additional research. For example, although some studies explored the relationship between coaching and performance (Agarwal et al., 2009; Ellinger et al., 2003; Pousa and Mathieu, 2014b), only a few studies tried to provide a rationale for this by identifying mediators (Pousa 2012; Pousa and Mathieu, 2014a). Identifying mediators, however, is a central issue because “... this information can be used to modify an intervention or for adapting its principles to another area ... mediators answer the question as to why an intervention worked" (Latham 2007, p. 64). Our results suggest that employee's self-efficacy is a valid mediator that explains why higher performance should follow coaching interventions.

However, the literature suggests that when people high on self-efficacy are faced with challenges they exert more effort, persist longer and make a better choice of alternative courses of action; when confronted with failure, people with higher self-efficacy better controlled their self-doubts, persisted longer in the goal pursuit, systematically tested alternative task-related plans and eventually obtained higher performance (Latham and Locke, 2007; Latham and Seijts, 1999; Latham and Pinder, 2005; Locke and Latham, 1990, 2002, 2006; Seijts and Latham, 2001). Accordingly, there might be additional mediators between self-efficacy and performance that are triggered by the coaching intervention and are yet to be identified and studied in future research. 


\section{References}

Agarwal, R., Angst, C. \& Magni, M. (2009). The Performance Effects of Coaching: A Multilevel Analysis using Hierarchical Linear Modeling, International Journal of Human Resource Management, 20(10), 2110-2134. DOI: 10.1080/09585190903178054

Bagozzi, R., \& Yi, Y. (1988). On the evaluation of structural equation models, Journal of the Academy of Marketing Science, 16(1), 74-84. Retrieved from http://search.proquest.com/abiglobal.

Bandura, A. (1977). Self-Efficacy: Toward a unifying theory of behavioral change, Psychological Review, 84 (2), 191-215. Retrieved from http://search.proquest.com/abiglobal.

Bandura, A. (1982). Self-Efficacy Mechanism in Human Agency, American Psychologist, 37 (February), 122-147. Retrieved from http://search.proquest.com/abiglobal.

Bandura, A. (1991). Social Cognitive Theory of Self-Regulation, Organizational Behavior and Human Decision Processes, 50, 248-287. Retrieved from http://search.proquest.com/abiglobal.

Bandura, A. and Locke, E. A. (2003). Negative Self-Efficacy and Goal Effects Revisited, Journal of Applied Psychology, 88(1), 87-99. DOI: 10.1037/0021-9010.88.1.87

Baron, L. \& Morin, L. (2010). The impact of executive coaching on self-efficacy related to management soft skills, Leadership \& Organizational Development Journal, 31(1), 1838. DOI 10.1108/01437731011010362

Byrne, B. (2010). Structural Equation Modeling with AMOS: basic concepts applications and programming. New York, NY: Rutledge, 2nd edition.

Cohen, J. (1976). Statistical Power Analysis for the Behavioral Sciences. Orlando, FL: Academic Press Inc., Revised Edition.

Corcoran, K., Petersen, L., Baitch, D. \& Barret, M. (1995). High Performance Sales organizations: Achieving competitive advantage in the Global Marketplace. Chicago, IL: IRWIN Professional Publications.

Cote, J. A., \& Buckley, M. R. (1987). Estimating trait, method and error variance: Generalizing across 70 construct validation studies, Journal of Marketing Research, 24(3), 315-318. Retrieved from http://search.proquest.com/abiglobal.

Ellinger, A. D., Ellinger, A. E. \& Keller, S. B. (2003). Supervisory Coaching Behavior, Employee Satisfaction, and Warehouse Employee Performance: A Dyadic Perspective in the Distribution Industry, Human Resource Development Quarterly, 14(Winter), 435458. Retrieved from http://search.proquest.com/abiglobal.

Ellinger, A. D., Hamlin, R. G. \& Beattie, R. S. (2008). Behavioural Indicators of Ineffective Managerial Coaching, A cross-national study, Journal of European Industrial Training, 32(4), 240-257. DOI 10.1108/03090590810871360

Ellinger, A. E., Ellinger, A. D. \& Keller, S. B. (2005). Supervisory coaching in a logistics context, International Journal of Physical Distribution and Logistics Management, 35(9), 620-636. DOI 10.1108/09600030510634562 
Fang, E. , Palmatier, R. W. \& Evans, K. R. (2004). Goal-Setting Paradoxes? Trade-Offs Between Working Hard and Working Smart: The United States versus China, Journal of the Academy of Marketing Science, 32(Spring), 188-202. DOI 10.11770092070303261413

Fornell, C., \& Larcker, D. (1981). Evaluating structural equations models with unobservable variables and measurement error, Journal of Marketing Research, 18, 39-50. Retrieved from http://search.proquest.com/abiglobal.

Fournies, F. (1978).Coaching for improved work performance, New York, NY: Van Nostrand Reinhold.

Gerbing, D. W. \& Anderson, J. C. (1988). An Updated Paradigm for Scale Development Incorporating Unidimensionality and Its Assessment, Journal of Marketing Research, 25(2), 186-192. Retrieved from http://search.proquest.com/abiglobal.

Gist, M. E. \& Mitchell, T. H. (1992). Self-Efficacy: A Theoretical Analysis of its Determinants and Malleability, Academy of Management Review, 17(April), 183-211. Retrieved from http://search.proquest.com/abiglobal.

Gordon Bar, S. \& St. Rosh-Ha'Ayin, D. (2014). How personal systems coaching increases selfefficacy and well-being for Israeli single mothers, International Journal of Evidence Based Coaching and Mentoring, 12(2), 59-74. Retrieved from http://business.brookes.ac.uk/ijebcm

Grant, A. M. (2010). It takes time: A stage of change perspective on the adoption of workplace coaching skills, Journal of Change Management, 10(1), 61-77.

DOI:10.1080/14697010903549440

Grant, A. M. \& Cavanagh, M. J. (2004). Toward a profession of coaching : Sixty-five years of progress and challenges for the future, International Journal of Evidence Based Coaching and Mentoring, 2(1), 1-16. Retrieved from http://business.brookes.ac.uk/ijebcm

Grant, A. M. \& Hartley, M. (2013). Developing the leader as coach: insights, strategies and tips for embedding coaching skills in the workplace, Coaching: An International Journal of Theory, Research and Practice, 6(2), 102-115. DOI: 10.1080/17521882.2013.824015

Guba, E. \& Lincoln Y. (1989). Fourth Generation Evaluation, Newbury Park, CA: Sage.

Hagen, M. S. (2012). Managerial coaching: A review of the literature, Performance Improvement Quarterly, 24(4), 17-39. DOI: 10.1002/piq.20123

Hamlin, R. G., Ellinger, A. D. \& Beattie, R. S. (2006). Coaching at the heart of managerial effectiveness: A Cross-cultural study of managerial behaviours, Human Resource Development International, 9(3), 305-331. DOI: 10.1080/13678860600893524

Hargrove, R. (1995) Masterful Coaching. Extraordinary Results by Impacting People and the Way They Think and Work Together. San Francisco CA: Pfeiffer.

Ingram, T. N., LaForge, R., Locander, W., MacKenzie, S. \& Podsakoff P. (2005). New Directions in Sales Leadership Research, Journal of Personal Selling and Sales Management, 25(2), 137-154. Retrieved from http://search.proquest.com/abiglobal. 
Joo, B. (2005). Executive coaching: A conceptual framework from and integrative review of practice and research, Human Resource Development Review, 4, 462-488. DOI: $10.1177 / 1534484305280866$

Kilburg, R. (1996). Toward a conceptual understanding and definition of executive coaching, Consulting Psychology Journal: Practice and Research, 48(2), 134-144. Retrieved from http://search.proquest.com/abiglobal.

Kinlaw, D. C. (1989). Coaching for Commitment: Managerial strategies for obtaining superior performance. San Diego, CA: Pfeiffer \& Company.

Klein, H. J., Wesson, M. J., Hollenbeck, J. R., Wright, P.M. \& DeShon, R. P. (2001). The Assessment of Goal Commitment: A Measurement Model Meta-Analysis, Organizational Behavior and Human Decision Processes, 85(1), 32-55. DOI:10.1006/obhd.2000.2931

Kline, R. B. (2011). Principles and Practice of Structural Equation Modeling (3 ${ }^{\text {rd }}$ Edition), New York, NY: Guilford Press.

Latham, G. P. (2007). Work Motivation: History, Theory, Research and Practice, Thousand Oaks, CA: SAGE Publications Inc.

Latham, G. P. \& Locke, E. A. (2007). New Developments in and Directions for Goal-Setting Research, European Psychologist, 12(4), 290-300. DOI 10.1027/1016-9040.12.4.290

Latham, G. P. \& Pinder, C. C. (2005). Work Motivation Theory and Research at the Dawn of the Twenty-First Century, Annual Review of Psychology, 56, 485-516. Retrieved from http://search.proquest.com/abiglobal.

Latham, G. P. \& Seijts, G. H. (1999). The Effects of Proximal and Distal Goal on Performance on a Moderately Complex Task, Journal of Organizational Behavior, 20(4), 421-429. Retrieved from http://search.proquest.com/abiglobal.

Latham, G. P. \& Wexley, K. (1994). Increasing Productivity through Performance Appraisal $\left(2^{\text {nd }}\right.$ Edition $)$, Reading, Mass: Addison-Wexley Publishing Co.

Locke, E. A. \& Latham, G. P. (1990). A Theory of Goal Setting and Task Performance. Englewood Cliffs, NJ: Prentice Hall.

Locke, E. A. \& Latham, G. P. (2002). Building a Practically Useful Theory of Goal Setting and Task Motivation, American Psychologist, 57(9), 705-717. Retrieved from http://search.proquest.com/abiglobal.

Locke, E. A. \& Latham, G. P. (2006). New Directions in Goal-Setting Theory, Current Directions in Psychological Science, 15(5), 265-268. Retrieved from http://search.proquest.com/abiglobal.

Maxwell, J. A. (1997). Designing a qualitative study, In L. Bickman \& D. J. Rog (Eds.), Handbook of applied social research methods (pp. 69-98), Thousand Oaks, CA: Sage.

Moen, F. \& Allgood, E. (2009). Coaching and the effect on self-efficacy, Organization Development Journal, 27(4), 69-82. Retrieved from http://search.proquest.com/abiglobal.

Nunnally, J. C. (1978). Psychometric theory, New York, NY: McGraw-Hill. 
Onyemah, V. (2009). The Effects of Coaching on Salespeople's Attitudes and Behavior, European Journal of Marketing, 43(7/8), 938-960. DOI 10.1108/03090560910961461

Podsakoff, P. M., MacKenzie, S. B., Lee, J.-Y. \& Podsakoff, N. P. (2003). Common Method Biases in Behavioral Research: A Critical Review of the Literature and Recommended Remedies, Journal of Applied Psychology, 88(5), 879-903. DOI: 10.1037/00219010.88.5.879

Pousa, C. (2012). The Impact of Coaching on Salesperson's Performance and the Mechanisms that regulate this Relationship, doctoral dissertation, Universite de Sherbrooke, Canada.

Pousa, C. \& Mathieu, A. (2014a). Boosting Customer-Orientation through Coaching: A Canadian Study, International Journal of Bank Marketing, 32(1), 60-81. DOI 10.1108/IJBM-04-2013-0031

Pousa, C. \& Mathieu, A. (2014b). The influence of coaching on employee performance: Results from two international quantitative studies, Performance Improvement Quarterly, 27(3), 79-96. DOI: $10.1002 /$ piq. 21175

Richardson, L. (2009). Sales Coaching: Making the great leap from Sales Manager to Sales Coach ( $2^{\text {nd }}$ edition). New York: McGraw-Hill.

Robson, C. (2002). Real World Research. Malden, MA: Blackwell Publishing, $2^{\text {nd }}$ edition.

Schmitt, N. (1994). Method bias: the importance of theory and measurement, Journal of Organizational Behavior, 15(5), 393-398. Retrieved from http://search.proquest.com/abiglobal.

Smither, J.W., Walker, A.G. \& Yap, M.K. (2004). An examination of the equivalence of webbased versus paper-and-pencil upward feedback ratings: rater- and rate-level analyses, Educational and Psychological Measurement, 64(1), 40-61. Retrieved from http://search.proquest.com/abiglobal.

Spector, P. E. (1987). Method Variance as an Artifact in Self-reported Affect and Perceptions at Work: Myth or Significant Problem?, Journal of Applied Psychology, 72(3), 438-443. Retrieved from http://search.proquest.com/abiglobal.

Spector, P. E. (1994). Using Self-report Questionnaires in OB Research: A Comment on the Use of a Controversial Method. Journal of Organizational Behavior, 15(5), 385-392. Retrieved from http://search.proquest.com/abiglobal.

Spector, P. E. (2006). Method Variance in Organizational Research: Truth or Urban Legend?, Organizational Research Methods, 9(2), 221-232. Retrieved from http://search.proquest.com/abiglobal.

Stajkovic, A. D. \& Luthans, F. (1998). Self-Efficacy and Work Related Performance: A MetaAnalysis, Psychological Bulletin, 124 (2), 240-261. Retrieved from http://search.proquest.com/abiglobal.

Sujan, Harish, Barton A. Weitz and Nirmalya Kumar (1994). "Learning Orientation, Working Smart, and Effective Selling," Journal of Marketing, 58 (July), 39-52. Retrieved from http://search.proquest.com/abiglobal. 
Trépanier, C. (2010). Le Coaching du Directeur et la Performance du Vendeur : Une Approche Relationnelle, Doctoral dissertation, Université de Sherbrooke, Sherbrooke, Canada.

Whitmore, J. (1985). Coaching for Performance: A Practical Guide to growing your own Skills. San Diego, CA: Pfeiffer.

Wood, R. \& Bandura, A. (1989). Impact of Conceptions of Ability on Self-Regulatory Mechanisms and Complex Decision Making, Journal of Personality and Social Psychology, 56(3), 407-415. Retrieved from http://search.proquest.com/abiglobal. 
Table 1

Seniority and experience of the respondents

\begin{tabular}{|l|c|c|c|c|}
\hline & Mean & Std.Dev. & Max. & Min. \\
\hline $\begin{array}{l}\text { How many years have you been working for this } \\
\text { company? }\end{array}$ & 13.25 & 13.14 & 39 & 0 \\
\hline $\begin{array}{l}\text { How many years have you been working in this } \\
\text { position? }\end{array}$ & 8.96 & 8.54 & 35 & 0 \\
\hline How many years of selling experience do you have? & 15.35 & 10.25 & 39 & 0 \\
\hline
\end{tabular}


Construct items and factor loadings

Coaching $(\alpha=.948 ; \mathrm{CR}=.950 ; \mathrm{AVE}=.703)$

My coach ...

... uses analogies, scenarios and examples to help me learn.

... encourages me to broaden my perspectives by helping me to see the big picture.

... provides me with constructive feedback.

... solicits feedback from me to ensure that his/her interactions are helpful to me.

... provides me with resources so I can perform my job more effectively.

... asks questions rather than provide solutions, to help me think through issues.

... sets expectations with me and communicates the importance of those expectations to the broader goals of the organization

... role-plays with me to help me see different perspectives.

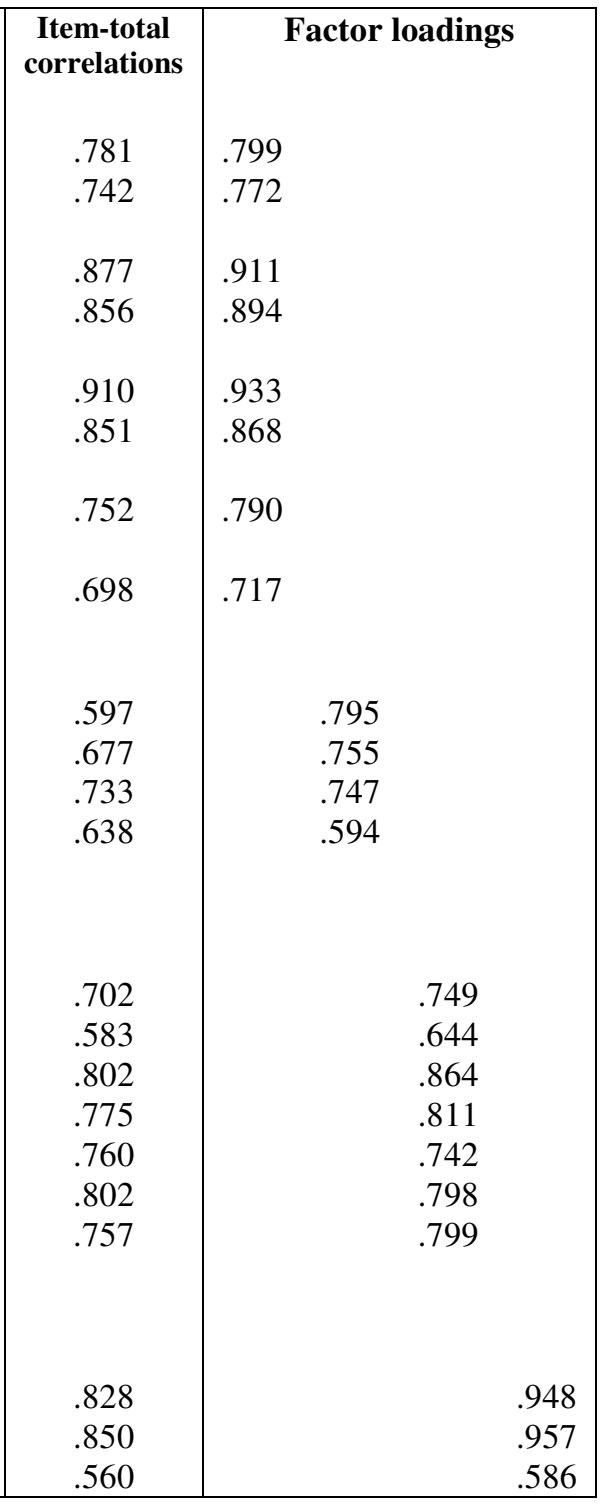

Self-efficacy $(\alpha=.838 ; \mathrm{CR}=.816 ; \mathrm{AVE}=.528)$

I am good at selling.

I know the right thing to do in selling situations.

I am good at finding out what customers want.

It is easy for me to get customers to see my point of view.

$\underline{\text { Performance-results }}(\alpha=.915 ; \mathrm{CR}=.913 ; \mathrm{AVE}=.601)$

I am very effective in ...

... contributing to my firm's market share.

... in selling products with the highest profit margins.

... generating a high level of dollar sales.

... quickly generating sales of newly introduced products.

... identifying major accounts in my territory.

... selling to major accounts.

... exceeding annual sales targets and objectives.

$\underline{\text { Performance-behavior }}(\alpha=.858 ; \mathrm{CR}=.881 ; \mathrm{AVE}=.719)$

I am very effective in ...

... assisting my supervisor in meeting his/her goals. 
Table 3

Factor correlations

\begin{tabular}{|l|ccc|cccc|}
\hline & Mean & S.D & AVE $^{1 / 2}$ & 1 & 2 & 3 & 4 \\
\hline 1. Coaching & 5.174 & 1.360 & .838 & $\mathbf{. 9 4 8}$ & & & \\
2. Self-efficacy & 5.830 & .840 & .727 & $.370^{* *}$ & $\mathbf{. 8 3 8}$ & & \\
3. Behavioural Performance & 5.540 & 1.060 & .848 & $.222^{*}$ & $.468^{* *}$ & $\mathbf{. 8 5 8}$ & \\
4. Results Performance & 5.310 & .942 & .775 & $.237^{*}$ & $.679^{* *}$ & $.671^{* *}$ & $\mathbf{. 9 1 5}$ \\
\hline
\end{tabular}

$\mathrm{AVE}^{1 / 2}$ is the square root of the Average Variance Extracted

Cronbach's alphas are presented in the main diagonal

** correlations are significant at 0.01 level (2-tailed)

* correlations are significant at 0.05 level (2-tailed) 
Table 4

Hypothesized main effects

\begin{tabular}{lccc|cc}
\hline \multirow{2}{*}{ Hypothesized path } & \multicolumn{3}{c|}{ (Not controlling for CMV) } & \multicolumn{2}{c}{ (Controlling for CMV) } \\
& $\begin{array}{c}\text { Standard path } \\
\text { coefficient }\end{array}$ & $\begin{array}{c}\mathrm{t}- \\
\text { Value }\end{array}$ & Hypothesis & \multicolumn{2}{c}{$\begin{array}{c}\text { Standard path } \\
\text { coefficient /t-values }\end{array}$} \\
\hline Coaching $\rightarrow$ Self-efficacy & .45 & $3.93^{*}$ & $\mathrm{H}_{1}$ & .45 & $4.18^{*}$ \\
Coaching $\rightarrow$ Performance (behavior) & .01 & n. s. & $\mathrm{H}_{2}$ & .00 & n.s. \\
Coaching $\rightarrow$ Performance (results) & -.06 & n. s. & $\mathrm{H}_{3}$ & -.02 & n.s. \\
Performance (behavior) $\rightarrow$ Performance (results) & .40 & $4.52^{*}$ & $\mathrm{H}_{4}$ & .44 & $4.72^{*}$ \\
Self-efficacy $\rightarrow$ Performance (behavior) & .51 & $3.62^{*}$ & $\mathrm{H}_{5}$ & .50 & $3.68^{*}$ \\
Self-efficacy $\rightarrow$ Performance (results) & .68 & $5.26^{*}$ & $\mathrm{H}_{6}$ & .65 & $5.09^{*}$ \\
$\mathrm{R}^{2}$ (Self-efficacy) & .20 & & & \multicolumn{2}{c}{.20} \\
$\mathrm{R}^{2}$ (Performance - results) & .85 & & & \multicolumn{2}{|c|}{.88} \\
$\mathrm{R}^{2}$ (Performance - behavior) & .26 & & & \multicolumn{2}{|c|}{.25} \\
\hline
\end{tabular}

$* \mathrm{p}<.01$ 
Figure 1

Results for the hypothesized model

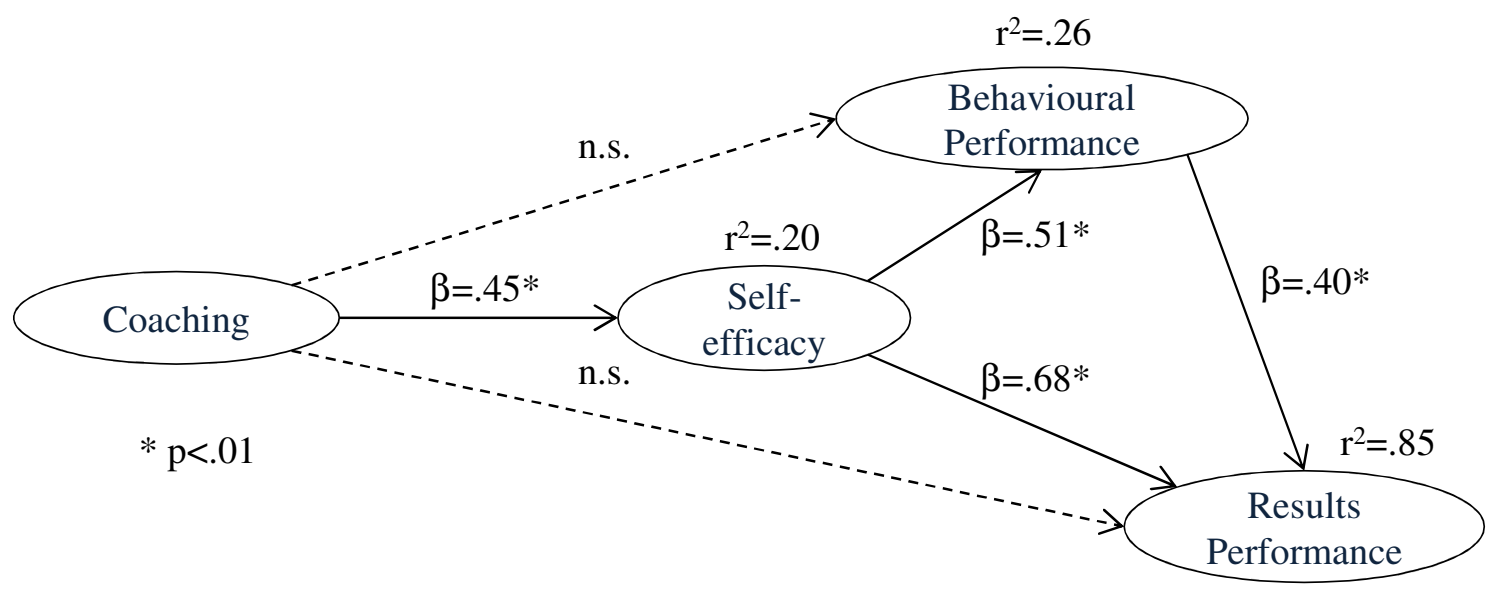

